\title{
Observations on dinoflagellate parasites of aloricate ciliates in Korean coastal waters
}

\author{
D. Wayne Coats ${ }^{1,4, *}$, Young Ok Kim², Jung Min $\mathrm{Choi}^{2}$, Eun Sun Lee ${ }^{3}$ \\ ${ }^{1}$ Smithsonian Environmental Research Center, PO Box 28, Edgewater, MD 21037, USA \\ ${ }^{2}$ Korea Institute of Ocean Science and Technology, Geoje 656-834, ROK \\ ${ }^{3}$ Department of Biological Sciences, University of Ulsan, Ulsan 680-749, ROK \\ ${ }^{4}$ Present address: 318 Bayard Road, Lothian, MD 20711, USA
}

\begin{abstract}
Parasites are an understudied but ecologically significant component of marine planktonic food webs. Syndinean dinoflagellates that infect tintinnid ciliates and free-living dinoflagellates cause host mortality that can lead to the decline of blooms and promote species succession. Far less is known about the role of parasitism in aloricate ciliates and other protistan groups. Here, we provide data on parasitism of aloricate ciliates for seasonal samples collected from the southern coast of Korea over a 3 yr period. Aloricate ciliates were parasitized by species from 2 syndinean dinoflagellate genera and an unidentified genus of core dinoflagellates (Dinokaryota). Morphological and developmental differences among parasites of different host taxa suggest high parasite diversity. Infections generally peaked in fall, but notable interannual variation was evident within seasons. Parasites were more often encountered in commonly occurring and abundant hosts, but were also detected in occasional and rare host species. Most host taxa were rarely or sporadically parasitized, but Strombidium pollostomum and Strombidium bilobum were infected in 31 and $13 \%$ of the samples, respectively, where the species were present. Parasite prevalence in those species reached 22 and $17 \%$, respectively. Overall, $29 \%$ of the samples analyzed contained infected aloricate ciliates. Results indicate that parasites of aloricate ciliates are usually a minor source of host mortality in coastal waters of Korea, but may periodically produce high infection levels contributing to top-down control of particular host species.
\end{abstract}

KEY WORDS: Ciliate $\cdot$ Dinoflagellate $\cdot$ Ecology $\cdot$ Parasitism

Resale or republication not permitted without written consent of the publisher

\section{INTRODUCTION}

Six species of syndinean dinoflagellates representing the genera Amoebophrya and Euduboscquella are known to parasitize marine tintinnid ciliates (see Coats \& Bachvaroff 2013 for review). These parasites are globally distributed in coastal and pelagic ecosystems where they produce epidemics that crop host biomass at rates similar to macrozooplankton grazers (Coats \& Heisler 1989, Coats et al. 1994). Two additional species, A. rosei and E. caryophaga, infect marine aloricate ciliates (Cachon \& Cachon 1987), but neither species has been studied since its original description. In addition, Bulit et al. (2013) reported a presumptive dinoflagellate as a parasite of the aloricate ciliate Cyrtostrombidium longisomum.

A. rosei is a hyperparasite (a parasite of a parasite) of apostome ciliates associated with siphonophores and chaetognaths, while E. caryophaga parasitizes free-living planktonic ciliates belonging to the genera Strombidium, Strobilidium, and Prorodon (Cachon 1964). Cachon (1964) did not identify the species of ciliates infected by A. rosei and E. caryophaga, making host range poorly defined. Also understudied is the temporal and spatial occurrence of syndinean species infecting aloricate ciliates, making speculation about their ecological significance tenuous at best. Cachon (1964), however, noted that infection of 
aloricate ciliates in Algiers Harbor was sporadic and rare, with examination of parasite morphology difficult due to the rapid swimming behavior and fragile nature of host cells.

During the initial stage of infection, A. rosei appears as a 6 to $7 \mu \mathrm{m}$ spherical body within the host cytoplasm and associates with the host nucleus (Cachon 1964). As the parasite grows, it undergoes nuclear and flagellar replication, eventually assuming a beehive appearance characteristic of the genus. The oblong to discoid 'beehive' stage of the mature parasite measures up to $150 \mu \mathrm{m} \times 75 \mu \mathrm{m}$ and emerges from the host cell only after the infected ciliate has departed its metazoan host. The extracellular 'vermiform' stage of A. rosei gradually elongates, attaining an impressive size of $4 \mathrm{~mm} \times 70 \mu \mathrm{m}$. Cachon (1964) was unable to follow the complete life cycle of $A$. rosei, but believed that dinospores formed from the 'vermiform' infect new apostome hosts before the ciliates re-infest their metazoan host organisms. If that is correct, then A. rosei would have the opportunity to infect free-living ciliates encountered in the plankton, a possibility that merits study.

E. caryophaga also grows within the host cytoplasm, but, as indicated by the species appellation, this parasite consumes the nucleus of its host (Cachon 1964). Early infection stages measure 4 to $5 \mu \mathrm{m}$ in diameter and are located adjacent to the ciliate's macronucleus. As the parasite grows, it presses against and gradually digests the host's macronucleus. Mature parasites are roughly spherical, reaching a maximum size of about $30 \mu \mathrm{m}$. Sporogenesis of E. caryophaga has not been studied, but is assumed to occur outside the host cell as in congeneric species.

While characterizing the ciliate microplankon community of Masan Bay, Korea in 2006 to 2008, we encountered dinoflagellate infections in aloricate ciliates at several stations. Here, we provide information on the host species that were parasitized, spatial and seasonal occurrence of infections, and gross morphology of parasite intracellular lifehistory stages. We also compare parasite morphology and development with that of species previously reported from ciliate hosts, as a first step in assessing the identity and diversity of syndinean dinoflagellates infecting free-living aloricate ciliates in Korean coastal waters.

\section{MATERIALS AND METHODS}

Water samples were collected from the surface of Masan Bay during 11 research cruises conducted between spring 2006 and fall 2008. Thirty-one stations were sampled in April, August, and November of 2006, and in February of 2007 (Fig. 1). For subsequent cruises, only a subset of the stations representing a longitudinal transect of Masan Bay to Geoje Island (Stns 1, 4, 7, 8, 14, 15, 18, and 31) were sampled. For each station, water obtained using a 51 Niskin bottle positioned $0.5 \mathrm{~m}$ below the surface was transferred to a $300 \mathrm{ml}$ plastic bottle and immediately preserved using concentrated Bouin's fluid (Coats \& Heinbokel 1982). The temperature and salinity of the surface water was determined using a data logging CTD (Surveyor 4a, Hydrolab).

Preserved samples were processed using the quantitative protargol staining (QPS) technique of Montagnes \& Lynn (1993), with 10 to $20 \mathrm{ml}$ volumes analyzed per station, depending on ciliate abundance. QPS preparations were examined at $\geq 200 \times$ and photographed at 400 to $1000 \times$ total magnification, using a Zeiss Primo Star or a Zeiss Axioscope 2 equipped with a Zeiss Axiocam ICC3 camera interfaced with a PC running Zeiss Axiovison software. Each QPS preparation was completely scanned to enumerate the total number of ciliates and to record the presence of infected specimens. Host cells were identified to genus or species using the primary literature and web-based resources (e.g. Lynn et al. 1988, Lynn \& Gilron 1993, Lee et al. 2011, 2012, Encyclopedia of Life http://eol.org). Graphics and statistical comparisons were generated using SPSS Systat software (SigmaPlot Version 11.0). Percent data were arcsin square-root-transformed and count data log-transformed prior to running statistical tests. Means \pm standard error are provided in the text.

\section{RESULTS}

\section{Temporal and spatial distribution}

Data for the 31 stations sampled from spring 2006 to winter 2007 showed marked spatial and temporal patterns in the occurrence of dinoflagellates infecting aloricate ciliates of Masan Bay, Korea (Fig. 1A-D). Infected hosts were very rare in spring and winter, being detected at only 1 station located in the upper reach of Masan Bay. By contrast, infections were relatively common in summer and fall, when they were encountered at 19 and $81 \%$ of the stations, respectively. Stations positive for parasites were restricted to the southern portion of the study area in summer, but were spread throughout the region in fall. The 
reduced number of stations sampled from spring 2007 to fall 2008 (Fig. 1E-K) failed to show a strong seasonal signal in the occurrence of parasites, although half of the stations were positive for parasites in the fall of both years. Notable interannual variation in seasonal parasitism of aloricate ciliates is also evident from these data. For example, $50 \%$ of the stations had infected hosts in winter 2008 in contrast to no parasites being detected in winter 2007 (cf. Fig. 1D and G). Of the 180 samples analyzed for the 3 yr study, 53 (29\%) contained infected aloricate ciliates.

Averaged across years, percent stations showing infections peaked in fall at $60 \%$ (Fig. 2). Values recorded for other seasons, however, were not significantly lower ( $p=0.26$, 1 -way ANOVA). Abundance of aloricate ciliates averaged across years was highest in spring, with sharply lower values recorded in other seasons. Seasonal means for percent stations having infected hosts were not correlated with seasonal means for total aloricate ciliate abundance $(p>0.05$; Pearson product-moment correlation). When plotted on a temperature-salinity parameter space (Fig. 3), stations positive for parasites were distributed across the full temperature and salinity range, but tended to be more frequent at slightly higher temperatures $\left(\geq 15^{\circ} \mathrm{C}\right)$ and salinities ( $\geq 28$ PSU).
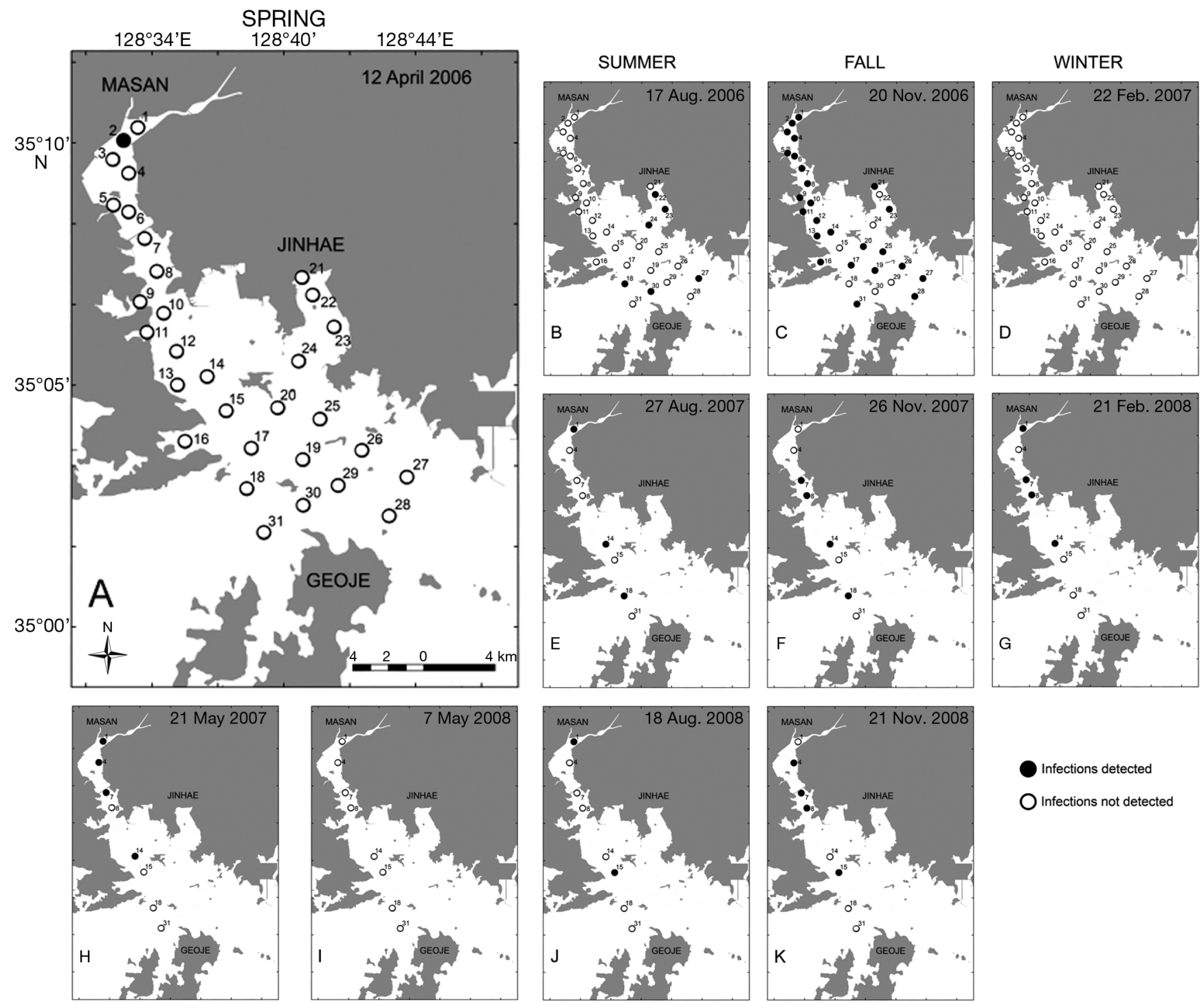

Infections detected

Infections not detected

Fig. 1. (A-K) Maps of the study area providing dates, station locations, and occurrence of parasitism in aloricate ciliates for each of the 11 cruises conducted between spring 2006 and fall 2008. Stations marked by black circles indicate that infected aloricate ciliates were detected, while those marked by white circles indicate that infected host cells were not observed 


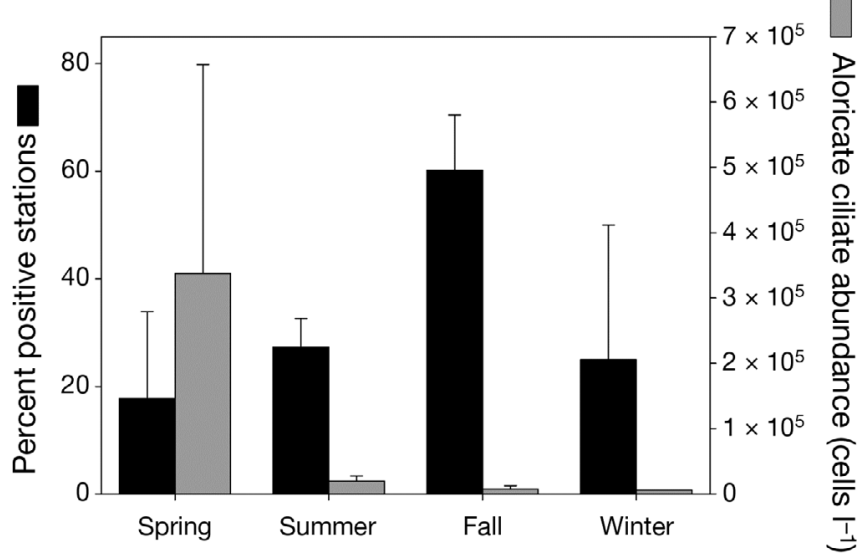

Fig. 2. Seasonal means for percent stations positive for parasites of aloricate ciliates and aloricate ciliate abundance. Error bars represent standard error of the mean, with sample size of 3 for spring, summer, and fall and 2 for winter

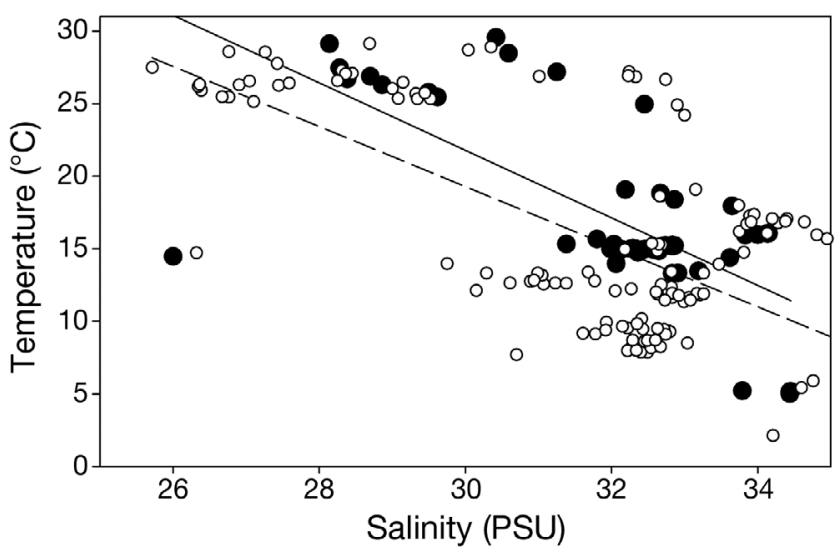

Fig. 3. Temperature-salinity parameter space showing samples where parasites of aloricate ciliates were (black circles) and were not (white circles) detected. Regression lines are provided for visualization purposes only, with solid and broken lines representing samples positive and negative for parasites, respectively

\section{Host taxa and parasite prevalence}

Of the 17 host taxa (Table 1), 15 harbored parasitic syndinean dinoflagellates and 2 were infected by parasites tentatively identified as core dinoflagellates (i.e. belonging to the subphylum Dinokaryota) based on the dinokaryon-like appearance of the nucleus in stained preparations. The number of taxa infected was highest in fall (10 species), with only 2 of those taxa (Strombidium bilobum and Strombidium pollostomum) being parasitized in other seasons. Cyrtostrombidium wailesi, Omegastrombidium kahli, Strombidinopsis acuminata, Strombidinopsis chilorhax, and Strombidinopsis minima were infected only in summer, while Strombidium tressum was parasitized only
Table 1. Seasonal occurrence of parasites in aloricate ciliate taxa

\begin{tabular}{|c|c|c|c|c|}
\hline Host taxa & Spring & Summer & Fall & Winter \\
\hline Cyclotrichium sp. & & & + & \\
\hline Cyrtostrombidium boreale & & & + & \\
\hline Cyrtostrombidium wailesi & & + & & \\
\hline Omegastrombidium kahli & & + & & \\
\hline Pelagostrobilidium sp. & & & + & \\
\hline Strombidium bilobum & + & & + & \\
\hline Strombidium compressum & & & + & \\
\hline Strombidium constrictum & & & + & \\
\hline Strombidium capitatum & & & & + \\
\hline Strombidium pollostomum & $2+$ & & + & + \\
\hline Strombidium tressum & + & & & \\
\hline Strombidium sp. & & & + & \\
\hline Strombidinopsis acuminata & & + & & \\
\hline Strombidinopsis chilorhax & & + & & \\
\hline Strombidinopsis minima & & + & & \\
\hline Strombidiidae unidentified & & & + & \\
\hline Tiarina fusus & & & + & \\
\hline Number of host taxa & 3 & 5 & 10 & 2 \\
\hline
\end{tabular}

in spring and Strombidium capitatum only in winter. Infections occurred more often in common host taxa, with $40 \%$ of the 10 most frequently encountered aloricate ciliates and $50 \%$ of the 10 most abundant taxa harboring parasites (Fig. 4). Note, however, that some rare and occasionally encountered species were also infected.

The 2 most frequently infected aloricate ciliates (S. pollostomum and $S$. bilobum) were parasitized in 15 or more samples, while the remaining host taxa had parasites in $\leq 6$ samples (Fig. 5). S. pollostomum and $S$. bilobum showed infections in $31 \%(\mathrm{n}=80)$ and $13 \%(\mathrm{n}=114)$ of the samples, respectively, where the species were present. For both species, mean host abundance at stations positive for infections was significantly higher $(\mathrm{p}<0.05)$ than stations where infections were not detected; values for $S$. pollostomum and $S$. bilobum, respectively, were $2100+360 /-310$ cells $\mathrm{l}^{-1}(\mathrm{n}=25)$ and $1390+320 /-260$ cells $\mathrm{l}^{-1}(\mathrm{n}=15)$ when parasites were detected vs. $1150+230 /-190$ cells $l^{-1}$ ( $\mathrm{n}=55)$ and $490 \pm 60$ cells $^{-1}(\mathrm{n}=99)$ when parasites were not detected; values represent back transformations of log-transformed data. Infection prevalence (\% host cells infected) for samples positive for parasites averaged $8 \pm 1.4 \%$ (range $=1$ to $22 \%$ ) and $6 \pm 1.2 \%$ (range $=1$ to $17 \%$ ) for the 2 species, respectively.

\section{Parasite morphology and development}

Parasites infecting $S$. pollostomum and Cyclotrichium sp. were tentatively identified as Amoebo- 

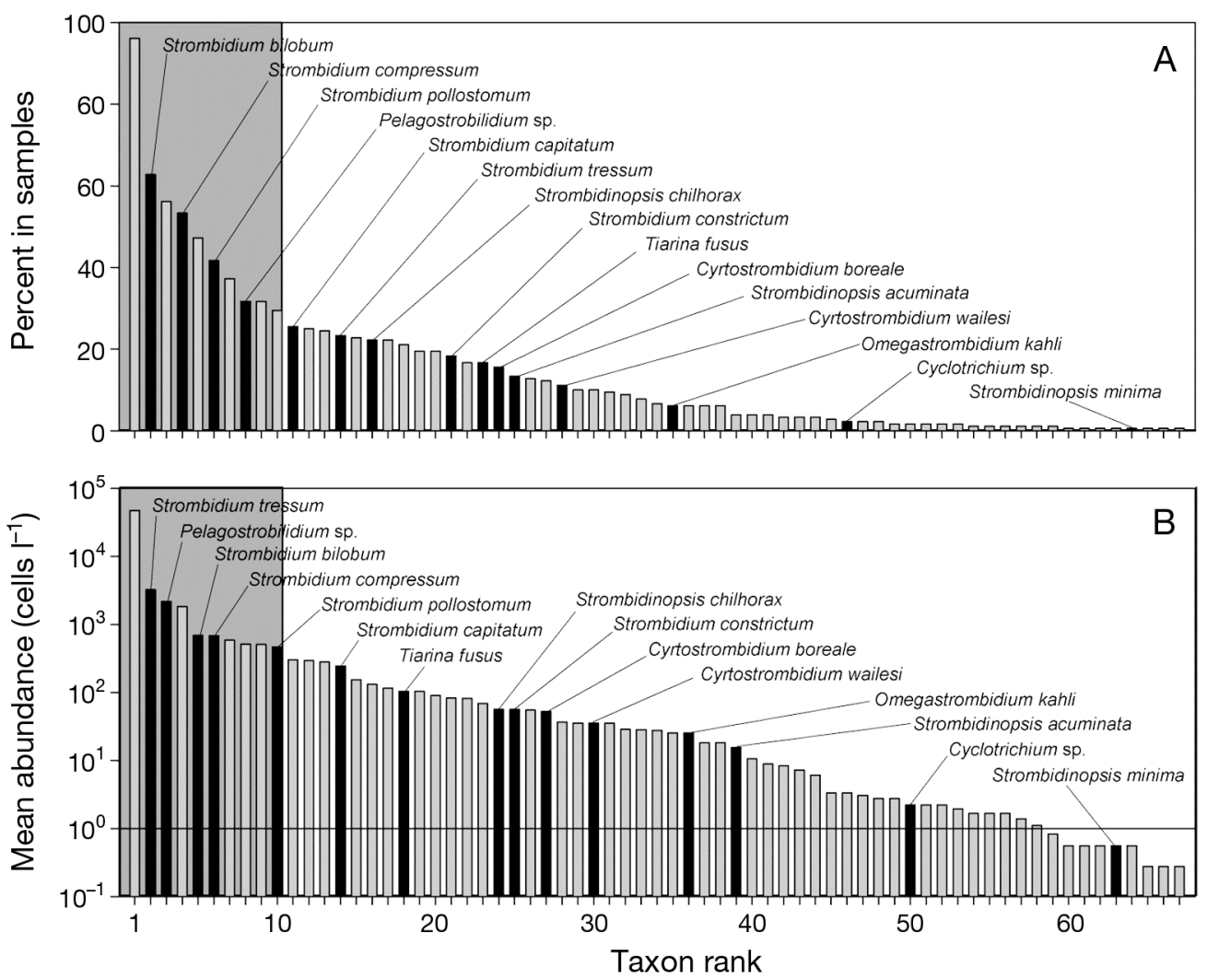

Fig. 4. Frequency distributions for aloricate ciliate taxa ranked as (A) percent occurrence in samples and (B) mean abundance. Black bars with corresponding identifications indicate parasitized taxa. Shaded area corresponds to the 10 most common or abundant host taxa. The infected Strombidium sp. and unidentified strombidiid are not included, due to uncertainty about their placement in the frequency distribution

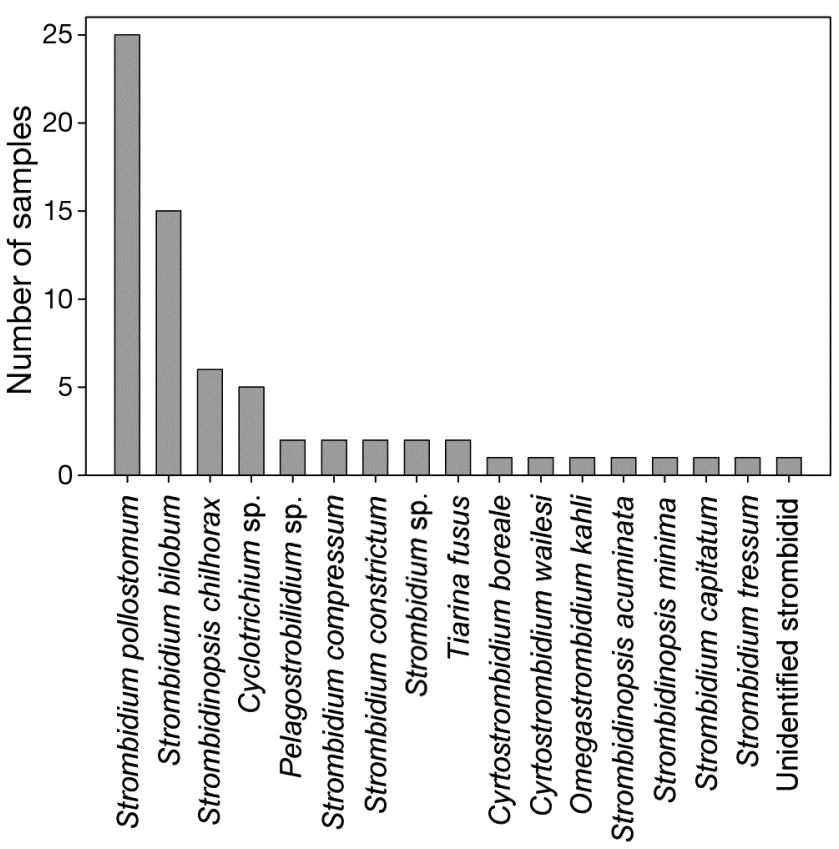

Fig. 5. Frequency distribution showing the number of samples in which each host taxon was parasitized phrya species. Early infection stages of Amoebophrya cf. sp. in $S$. pollostomum occurred in the host nucleus, measured $\geq 5 \mu \mathrm{m}$ in diameter, had a distinct acentric nucleolus, and lacked clearly defined chromosomes (Fig. 6A). As the parasite grew, it consumed the host nucleus and cytoplasm, eventually producing a roughly spherical, $\sim 15 \mu \mathrm{m}$ diameter mass that distorted the posterior outline of the infected ciliate (Fig. 6B). Division of the parasite nucleus was delayed, with daughter nuclei forming only after development of a flattened mastigocoel (flagellar cavity) and broad tubular lamina pharyngia (presumptive cytopharynx; Fig. 6B). Amoebophrya cf. sp. from Cyclotrichium sp. (Fig. 6C) developed in the cytoplasm of the host, but otherwise resembled specimens infecting $S$. pollostomum.

Euduboscquella cf. species (Fig. 6D-J) were encountered in O. kahli, Pelagostrobilidium sp., Strombidium bilobum, S. capitatum. S. compressum, S. constrictum, S. tressum, Strombidium sp., Strombidinopsis acuminata, S. chilorhax, S. minima, the unidentified strombidiid, and Tiarina fusus. Parasites were 


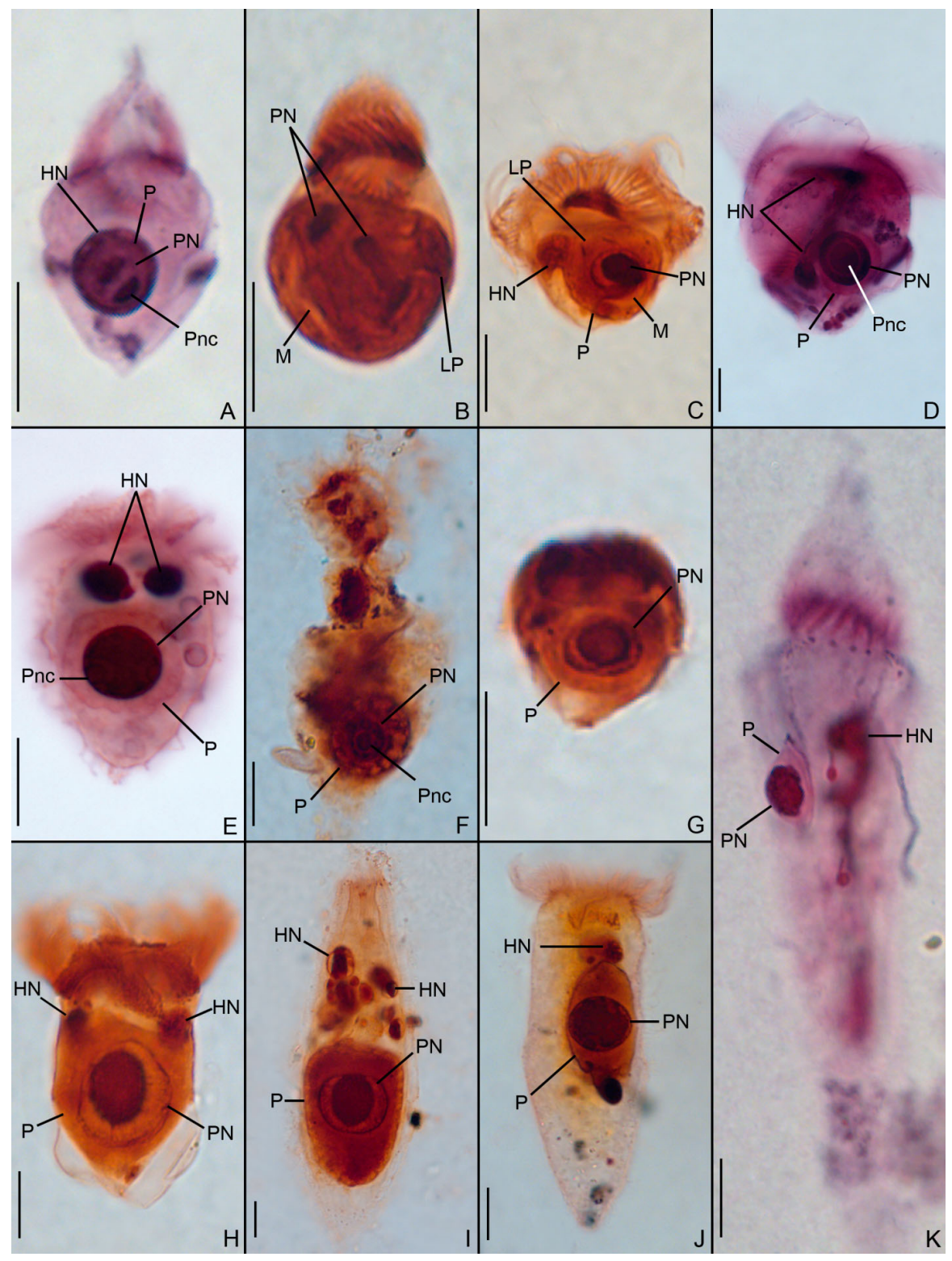

Fig. 6. Protargol-stained aloricate ciliates infected by parasitic dinoflagellates. (A) A very early infection of Amoebophrya cf. sp. located in the nucleus of Strombidium pollostomum. Note the parasite nucleolus. (B) S. pollostomum with mid- to late beehive stage of Amoebophrya cf. sp. showing mastigocoel, lamina pharyngia, and multiple parasite nuclei. (C) Early beehive stage of Amoebophrya cf. sp. in the cytoplasm of Cyclotrichium sp. (D) Strombidium capitatum infected by Euduboscquella cf. sp. in early to mid-stage of infection. Note the large parasite nucleolus. (E) Strombidinopsis chilorhax with Euduboscquella cf. sp. in mid-stage infection. (F) An unidentified strombidiid ciliate containing an early to mid-stage of Euduboscquella cf. sp. Note the vacuolated cytoplasm surrounding the parasite nucleus. (G) Pelagostrobilidium sp. with mature infection of Euduboscquella cf. sp. (H) Mature Euduboscquella cf. sp. in Strombidium bilobum. (I) Tiarina fusus with Euduboscquella cf. sp. at maturity. Note the fragmented host nucleus. (J) Strombidinopsis acuminata with a mature infection of Euduboscquella cf. sp. (K) Cyrtostrombidium boreale with an early infection produced by an ectoparasite tentatively identified as belonging to the core dinoflagellates. Abbreviations: $\mathrm{HN}=$ host nucleus; $\mathrm{M}=$ mastigocoel $; \mathrm{LP}=$ lamina pharyngia; $\mathrm{PN}=$ parasite nucleus; $\mathrm{Pnc}=$ parasite nucleolus; $\mathrm{p}=$ parasite; Scale bars $=10 \mu \mathrm{m}$

located in the cytoplasm of Pelagostrobilidium sp., $S$. bilobum, S. capitatum. S. compressum, S. constrictum, S. tressum, S. acuminata, S. chilorhax, S. minimum, and T. fusus, with host nuclei present even in very late-stage infections. In T. fusus, however, the nucleus of infected cells was separated into several ovoid fragments (Fig. 6I). Host nuclei were not observed in parasitized Strombidium sp. and the 
unidentified strombidiid; therefore, whether these host taxa were infected by a cytoplasmic or a nuclear parasite remains uncertain. Similarly, the site of infection for Euduboscquella cf. species in O. kahli remains uncertain, as the single specimen encountered was in a late stage of development with multiple host macronuclei still present. Thus, the parasite may have developed in the host cytoplasm or in one of the host's many macronuclei. All immature stages of Euduboscquella cf. sp. had a spherical nucleus with 1 or 2 large nucleoli and lacked clearly defined chromosomes (Fig. 6D-F). Immature parasites from the unidentified strombidiid, however, differed from those of other host species by having a highly vacuolated, honeycomb-like cytoplasmic matrix (Fig. 6F). Mature infections, recognized as parasites with an amorphous nuclear matrix and occupying most of the host volume, also showed morphological differences across host species. For example, mature infections ranged from spherical cells having a maximum diameter of $11 \mu \mathrm{m}$ in Pelagostrobilidium sp. (Fig. 6G), to conically shaped cells with maximum dimensions of $27 \mu \mathrm{m} \times 22 \mu \mathrm{m}$ in $S$. bilobum (Fig. 6H), cylindrical cells measuring up to $41 \times 29 \mu \mathrm{m}$ in T. fusus (Fig. 6I), and prolate spheroids $23 \mu \mathrm{m} \times 13 \mu \mathrm{m}$ in $S$. acuminata (Fig. 6J). Division of the parasite nucleus was not observed in any of the Euduboscquella cf. species infecting aloricate ciliates.

Unlike the syndinean parasites considered above, the presumptive dinokaryote parasite infecting Cyrtostrombidium boreale and C. wailsei were attached to the outside of the host cell (Fig. 6K). The nucleus of the parasite also differed from that observed in Amoebophrya cf. species and Euduboscquella cf. species, as it appeared to have well-defined chromosomes. Mature stages of this parasite were not observed.

\section{DISCUSSION}

Cachon (1964) reported that parasitism of planktonic aloricate ciliates was rare and sporadic in summer. Similarly, a recent 57 wk study of Cyrtostrombidium longisomum in a tidal lagoon on the Pacific coast of Mexico revealed sporadic occurrence of a presumptive parasitic dinoflagellate during spring, with up to 7 of 10 cells infected in a single sample from March (Bulit et al. 2013). Parasitism of aloricate ciliates in Masan Bay, Korea was not uncommon, occurring in $29 \%$ of our samples. Nonetheless, most of the 17 host taxa we observed were infected in only a few samples, making parasitism at the species level generally rare. Infection of 2 host species, Strombid- ium pollostomum and Strombidium bilobum, however, was reasonably common, with parasitized specimens occurring in 31 and $13 \%$ of our samples, respectively, where the species were present.

Seasonal patterns in parasitism of planktonic protists have been previously reported for tintinnid ciliates and free-living dinoflagellates (Coats \& Heisler 1989, Park et al. 2013). For both host groups, parasitism by syndinean dinoflagellates is typically most common in mid- to late summer; however, infection of some free-living dinoflagellate host taxa occurs throughout the year. Also, some species of core dinoflagellates (i.e. Dinokaryota) that infect tintinnids can reach peak prevalence during winter (e.g. Tintinnophagous acutus; D. W. Coats pers. obs.). In contrast, our data for aloricate ciliates showed the highest occurrence of parasitism during fall (i.e. November). Temporal resolution of our samples and observed interannual variation in parasitism, however, leaves open the possibility that parasites may be common at other times of the year. That potential seems likely given that aloricate ciliates were infected across the full temperature and salinity range observed during our study.

The apparent seasonality in occurrence of parasites in aloricate ciliates of Masan Bay did not mirror the seasonal pattern in total abundance of aloricate ciliates. That observation is not surprising, given that parasites are often host specific, as has been reported for syndinean species that infect dinoflagellate hosts (Park et al. 2013). Thus, one might expect the occurrence of parasites in planktonic ciliates to more closely reflect the abundance of each host species. While Coats \& Heisler (1989) documented a repeating seasonal pattern in parasitism of the loricate ciliate Eutintinnus pectinis, a strong link between host abundance and parasite prevalence was not apparent in discrete samples. When integrated over the water column, however, parasite prevalence and host abundance were positively correlated. The weak association between host abundance and parasitism of $E$. pectinis in discrete samples was presumably due to epidemics that caused the decline of host populations, resulting in low tintinnid abundances with high parasite prevalence. Addressing species-level associations for parasites observed in our samples is problematic, as most host taxa were infected in only a few samples. S. pollostomum and $S$. bilobum, however, were parasitized in 25 and 15 samples, respectively, with mean host abundance at stations positive for infections being significantly higher than at stations negative for parasites. Thus, parasitism of these 2 host species may be influenced by host density. 
Most parasites observed in aloricate ciliates of Masan Bay were provisionally assigned to the syndinean genera Amoebophrya and Euduboscquella; however, 2 parasites were tentatively identified as core dinoflagellates. Amoebophrya cf. species infecting $S$. pollostomum and Cyclotrichium sp. developed in the nucleus and cytoplasm of the host, respectively, but were otherwise indistinguishable in our stained preparations. The discrepancy in site of infection and the phylogenetic distance between the 2 host species, however, suggests that S. pollostomum and Cyclotrichium sp. may be infected by separate parasite species. Support for that notion can be found in molecular studies of the Amoebophrya ceratii complex infecting free-living dinoflagellates. Thus far, rDNA sequences for strains of the $A$. ceratii complex cultured in different dinoflagellate species, or obtained by single-cell PCR of different host species isolated from field samples, are sufficiently different to support separation of the parasites at the species level (Kim et al. 2008, Park et al. 2013). In addition, only one cultured isolate of the $A$. ceratii complex is known to develop in both the cytoplasm and nucleus of the host, the latter occurring only in host cells that have multiple infections (Kim et al. 2008). Amoebophrya cf. species from $S$. pollostomum and Cyclotrichium sp. differed from A. rosei (Cachon 1964) in size and shape of the mature parasite (spherical with maximum diameter of $\sim 15 \mu \mathrm{m}$ vs. discoid with maximum dimensions of $150 \mu \mathrm{m} \times 75 \mu \mathrm{m}$, respectively). In addition, the parasite of $S$. pollostomum differed from $A$. rosei by producing nuclear rather than cytoplasmic infections, while the parasite of Cyclotrichium differed from $A$. rosei by forming cytoplasmic infections that did not appear to digest the host nucleus. Morphological comparison of the parasites from $S$. pollostomum and Cyclotrichium sp. with Amoebophrya species from loricate ciliates or other protistan groups is premature due to the lack of detailed morphological analyses. Nonetheless, infections observed in our 2 aloricate ciliates likely represent either new species or new host records if eventually determined to be a previously described species from tintinnids or other protists.

Euduboscquella cf. sp. from our samples showed noticeable morphological and developmental differences across host taxa, suggesting that aloricate ciliates of Masan Bay were infected by several different congeneric parasites. None of the Euduboscquella cf. sp. we observed closely resembled species known to infect tintinnids and dinoflagellate hosts (Cachon 1964, Coats \& Bachvaroff 2013). E. caryophaga, the only species of the genus described as a parasite of aloricate ciliates, develops in the host cytoplasm and consumes the host nucleus. Euduboscquella cf. species from Pelagostrobilidium sp., Strombidium bilobum, S. capitatum, S. compressum, S. constrictum, S. tressum, Strombidinopsis acuminata, S. chilorhax, S. minima, the unidentified strombidiid and Tiarina fusus developed in the host cytoplasm, but only the form infecting $T$. fusus appeared to disrupt or digest the host macronucleus. In addition, the mature parasite of Pelagostrobilidium sp., S. bilobum, Strombidium sp., T. fusus, and S. acuminata differed from E. caryophaga in size and shape, while the vacuolated cytoplasm of the immature parasite from the unidentified strombidiid differed from E. caryophaga and all other parasites we observed. Although our observations indicate that aloricate ciliates are infected by several species of Euduboscquella, careful morphological and molecular studies are needed to accurately assess species diversity and identification.

Two aloricate ciliates from Korean coastal waters, Cyrtostrombidium boreale and C. wailesi were infected by ectoparasites apparently belonging to a genus of core dinoflagellates. In both hosts, the parasites resembled the presumptive dinoflagellate found to infect $C$. longisomum on the Pacific coast of Mexico (Bulit et al. 2013). Unlike our specimens, the presumptive dinoflagellate parasite of C. longisomum was reported to occur inside the host cell, but the image provided (Fig. 3h in Bulit et al. 2013; parasite on the right) could be interpreted as infection by a parasite attached to the host surface.

While parasitism of aloricate ciliates in Masan Bay is temporally and spatially widespread, most host taxa appear to be rarely or sporadically infected. Thus, parasitic dinoflagellates would not appear to have a major impact on host populations in that coastal system. Two host species, S. pollostomum and $S$. bilobum, however, were infected in multiple samples, with parasite prevalence reaching 22 and $17 \%$ respectively. For these species, mortality due to parasitism may represent a significant loss factor, as has been suggested for the presumptive dinoflagellate infecting $C$. longisomum on the Mexican coast (Bulit et al. 2013). Such extrapolations should, however, be viewed with caution, as data needed to calculate mortality due to parasitism (e.g. timing of the parasite infection cycles) are currently unavailable.

Acknowledgements. This work was supported by research grants PO00135 and PE00154 from the Korean Institute of Ocean Science and Technology (KIOST). 


\section{LITERATURE CITED}

Bulit C, Macek M, Montagnes D (2013) Insights on shortterm blooms of planktonic ciliates, provided by an easily recognised genus: Cyrtostrombidium. Acta Protozool 52: $1-12$

Cachon J (1964) Contribution a l'étude des péridiniens parasites. Cytologie, cycles évolutifs. Ann Sci Nat Zool 6: $1-158$

Cachon J, Cachon M (1987) Parasitic dinoflagellates. In: Taylor FJR (ed) The biology of dinoflagellates. Blackwell Science Publishing, Oxford, p 571-610

Coats DW, Bachvaroff TR (2013) Parasites of tintinnids. In: Dolan JR, Montagnes DJS, Agatha S, Coats DW, Stoecker DK (eds) The biology and ecology of tintinnid ciliates: models for marine plankton. Wiley-Blackwell, Chichester, p 145-170

Coats DW, Heinbokel JF (1982) A study of reproduction and other life cycle phenomena in planktonic protists using an acridine orange fluorescence technique. Mar Biol 67: 71-79

Coats DW, Heisler JJ (1989) Spatial and temporal occurrence of the parasitic dinoflagellate Duboscquella cachoni and its tintinnine host Eutintinnus pectinis in Chesapeake Bay. Mar Biol 101:401-409

Coats DW, Bockstahler KR, Berg GM, Sniezek JH (1994) Dinoflagellate infections of Favella panamensis from two North American estuaries. Mar Biol 119:105-113

Kim S, Park MG, Kim KY, Kim CH, Yih W, Park JS, Coats

Editorial responsibility: Urania Christaki, Wimereux, France
DW (2008) Genetic diversity of parasitic dinoflagellates in the genus Amoebophrya and its relationship to parasite biology and biogeography. J Eukaryot Microbiol 55: $1-8$

> Lee ES, Shin MK, Kim YO (2011) Morphological descriptions of four oligotrich ciliates (Ciliophora: Oligotrichia) from southern coast of Korea. Korean J Syst Zool 27: 131-141

Lee ES, Xu D, Shin MK, Kim YO (2012) First record of six marine ciliate species of genus Strombidium (Ciliophora: Spirotricha: Oligotrichia) from Korea with ecological notes. ASED 28:192-207

Lynn DH, Gilron GL (1993) Strombidiid ciliates from coastal waters near Kingston Harbour, Jamaica (Ciliophora, Oligotrichia, Strombidiidae). J Mar Biol Assoc UK 73: $47-65$

> Lynn DH, Montagnes DJS, Small EB (1988) Taxonomic descriptions of some conspicuous species in the family Strombidiidae (Ciliophora: Oligotrichida) from the Isles of Shoals, Gulf of Maine. J Mar Biol Assoc UK 68: 259-276

Montagnes DJS, Lynn DH (1993) A quantitative protargol stain (QPS) for ciliates and other protists. In: Kemp PF, Sherr BF, Sherr, EB, Cole JJ (eds) Handbook of methods in aquatic microbial ecology. Lewis Publishers, Boca Raton, FL, p 229-240

Park MG, Kim S, Shin EY, Yih W, Coats DW (2013) Parasitism of harmful dinoflagellates in Korean coastal waters. Harmful Algae 30:S62-S74

Submitted: November 28, 2013; Accepted: February 6, 2014 Proofs received from author(s): March 19, 2014 